$[\mathrm{CL}]$

\title{
A new genetic model for the East Taiwan Ophiolite and its implications for Dupal domains in the Northern Hemisphere
}

\author{
Sun-Lin Chung a and Shen-su Sun ${ }^{b}$ \\ "Department of Geology, National Taiwan Unicersity, 245 Choushan Road, Taipei 10770, Taiwan, ROC \\ ${ }^{b}$ Minerals and Land Use Program, Bureau of Mineral Resources, Geology and Geophysics, G.P.O. Box 378, Canberra, \\ ACT 2601, Australia
}

Received June 17, 1991; revision accepted December 26, 1991

\begin{abstract}
The Miocene East Taiwan Ophiolite (ETO) has been suggested to have been generated at an "abnormal" mid-ocean ridge along a transform fault in the South China Sea [1]. As a result of arc-continent collision, the ETO was fragmented and incorporated into the Pliocene Lichi Melange of the Coastal Range, eastern Taiwan. Based on the structure of the slow-spreading Mid-Atlantic Ridge and the Tethyan Ophiolites, a new genetic model is proposed for ETO: it was formed in a normal slow-spreading axis environment where serpentinized peridotites and gabbros had been exposed onto the ocean floor.

Further, we propose that ETO basalts which overlie pelagic red shales represent products of near-ridge seamounts erupted by the end of South China Sea spreading ( $\sim 15 \mathrm{Ma}$ ago). Basalt samples collected from small areas near Kuanshan in the Coastal Range, eastern Taiwan are characterized by simple mineralogy, general lack of hydrothermal alteration. abundance of commonly fresh glass (up to $95 \%$ by volume), and high $\mathrm{MgO}$ content averaging $8.8 \mathrm{wt} . \%$. In addition, they have considerably heterogeneous incompatible trace element (e.g. La/Sm ratios) and $\mathrm{Nd}$ and $\mathrm{Pb}$ isotope compositions. These characteristics are consistent with a magma origin from near-ridge seamounts.

The $\mathrm{Pb}$ isotope compositions of ETO basalts and post-spreading seamount basalts from the South China Sea have Dupal anomaly characters, containing higher ${ }^{208} \mathrm{~Pb} /{ }^{204} \mathrm{~Pb}$ ratios (with $\Delta^{208 / 204} \mathrm{~Pb}=31-74$ ) than MORB of the Northern Hemisphere. The South China Sea, from which the ETO originated, is the only domain where EM2 Dupal-type Pb composition has been found in well-developed spreading centres of the Northern Hemisphere. Since volcanism in this region was not associated with mantle plume activity, the observed Dupal $\mathrm{Pb}$ property is probably a result of melting of convecting mantle which has been contaminated by thermal erosion and delamination of continental lithosphere with EM2 character prior to or during the formation of the South China Sea.
\end{abstract}

\section{Introduction}

The East Taiwan Ophiolite (ETO) is one of the youngest ophiolite complexes in the world. It was formed at about $15 \mathrm{Ma}[1,2]$ and was emplaced through arc-continent collision at about 3-4 Ma [3-5]. More importantly, it provides the only currently available material for studying the South China Sea ocean floor.

The ETO displays some unusual geological, petrological and geochemical characteristics: (1) some basaltic lavas directly overlie peridotites, and show chilled margins along the contact [6]; (2) pelagic red shales occur intercalated between the extrusive and plutonic sequences [6,7]; (3) the basalts contain abundant glass (up to 95\%) and commonly have high $\mathrm{MgO}$ contents (up to 10.2 wt.\%) $[2,7,8]$; (4) samples collected from a small area show considerable variations of incompatible element abundances and isotope compositions $[2,9] ;(5) \mathrm{Pb}$ isotope compositions of the ETO basalts show a clear Dupal-type [10] character. The South China Sea, accordingly, appears to be the only region where Dupal-type $\mathrm{Pb}$ compositions have been found in well-developed spreading centres of the Northern Hemisphere.

In view of these particular properties, it is necessary to critically re-evaluate the surprisingly large amount of published data of the ETO for better understanding its genesis. In this paper, they will be evaluated in the light of some new 
observations at slow-spreading ridges and the geochemical characteristics of near-ridge seamount basalts. Finally, the origin of the Dupal isotopic anomaly will be discussed.

\section{Geotectonic framework}

Taiwan is a late Cenozoic orogenic belt generated by an oblique collision between the Luzon arc sitting on the Philippine Sea plate and the Eurasian continent (Fig. 1) [4,5 and references therein]. The Longitudinal Valley in eastern Taiwan has been considered as the boundary between these two plates (Fig. 2). As a result of eastward subduction of the South China Sea, the Luzon arc was formed and the ETO was incorporated-into the Lichi Melange as allochthonous blocks on the west side of the Coastal Range of
Taiwan. Being the northern extension of the Luzon arc, the Coastal Range was gradually accreted to the continental margin by northwestward motion of the Philippine Sea plate $[11,12]$ and the attached Lichi Melange was tectonically emplaced through the arc-continent collision $[1,3,5]$.

The Cenozoic tectonic evolution of Southeast Asia has been closely related to the India-Eurasia collision commencing about $50 \mathrm{Ma}$ ago. Opening of the South China Sea was consistent with the clockwise rotation of Indochina relative to South China and left-lateral movement along the Red River fault caused by this collision [13,14]. No deep-sea drilling has yet been undertaken in this marginal sea, but the seafloor magnetic data have been used to reconstruct the spreading history of the South China Sea which spans the mid-Oligo-

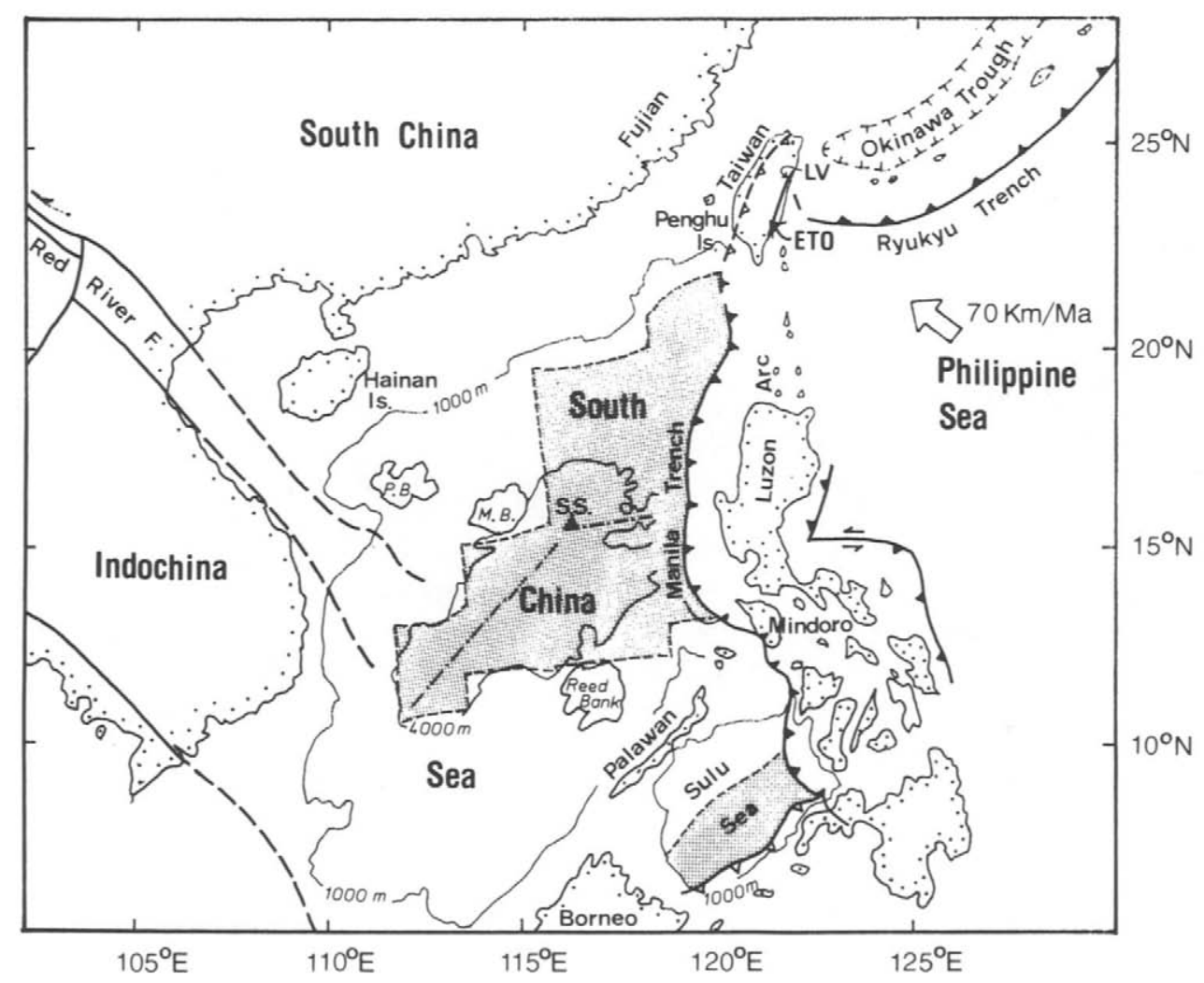

Fig. 1. Geotectonic framework of Southeast Asia. In the South China Sea, the oceanic crust (shaded area) is surrounded by microcontinental fragments, such as Paracel Bank (P.B.) and Macclesfield Bank (M.B.) to the north, and North Palawan and Reed Bank to the south. The Scarborough seamounts ( $\Delta$ marked by S.S.) are located close to or within the extinct spreading axis of the South China Sea (point-dash line). In Taiwan, the ETO is located on the west side of the Coastal Range, east to the Longitudinal Valley $(L V)$. Modified from $[4,5,15]$. 


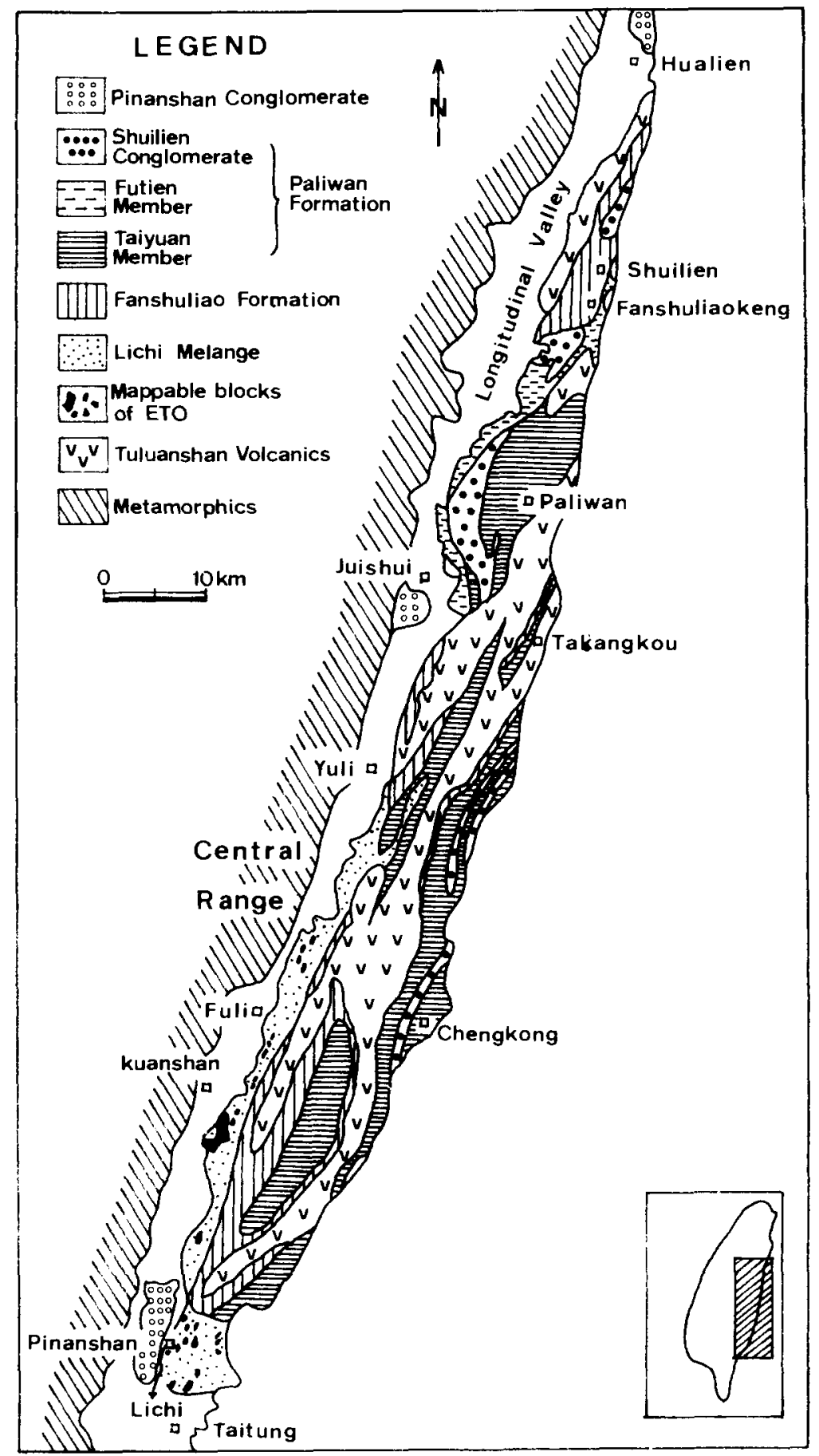

Fig. 2. Distribution of the ETO and the geologic map of the Coastal Range of Taiwan (after Liou et al. [7] and Teng [5], respectively). 
cene through Early Miocene $(\sim 32-15 \mathrm{Ma})$ $[15,16]$.

\section{Origin of the ETO}

Chai [17] proposed in 1972 that the mafic and ultramafic blocks in the Lichi Melange were parts of an ophiolite complex. In the same year Shih et al. [18] proposed the name "Coastal Range Ophiolite of Taiwan" and suggested an origin at an oceanic spreading centre based on petrological and geochemical data. Since then, detailed field and laboratory studies have been carried out resulting in a consensus that the ETO originated from a marginal basin, most likely the South China Sea $[1,2,7,19,20]$. A schematic geologic column has been constructed (Fig. 3) by Liou et al. [7] who coined the term "East Taiwan Ophiolite".

\subsection{Was the ETO generated at an "abnormal" MOR entironment?}

Suppe et al. [1] argued that "ETO was not formed at a normal oceanic spreading centre but rather has an unusual stratigraphy composed of submarine scree deposits consisting of angular mafic and ultramafic plutonic clasts and overlying basaltic flows that accumulated below the calcite compensation depth along a fault scarp in disturbed, preexisting oceanic crust". They suggested the setting to be a leaky transform fault offsetting mid-ocean ridge with a crest form like the East Pacific Rise [21]. Since the ETO exists as chaotic fragments within the Lichi Melange, the preserved ophiolitic sequence was explained to be the most surficial parts of this "atypical" section of the oceanic crust.

As shown in Fig. 3, the ETO can be grouped into two units: the lower plutonic sequence com-

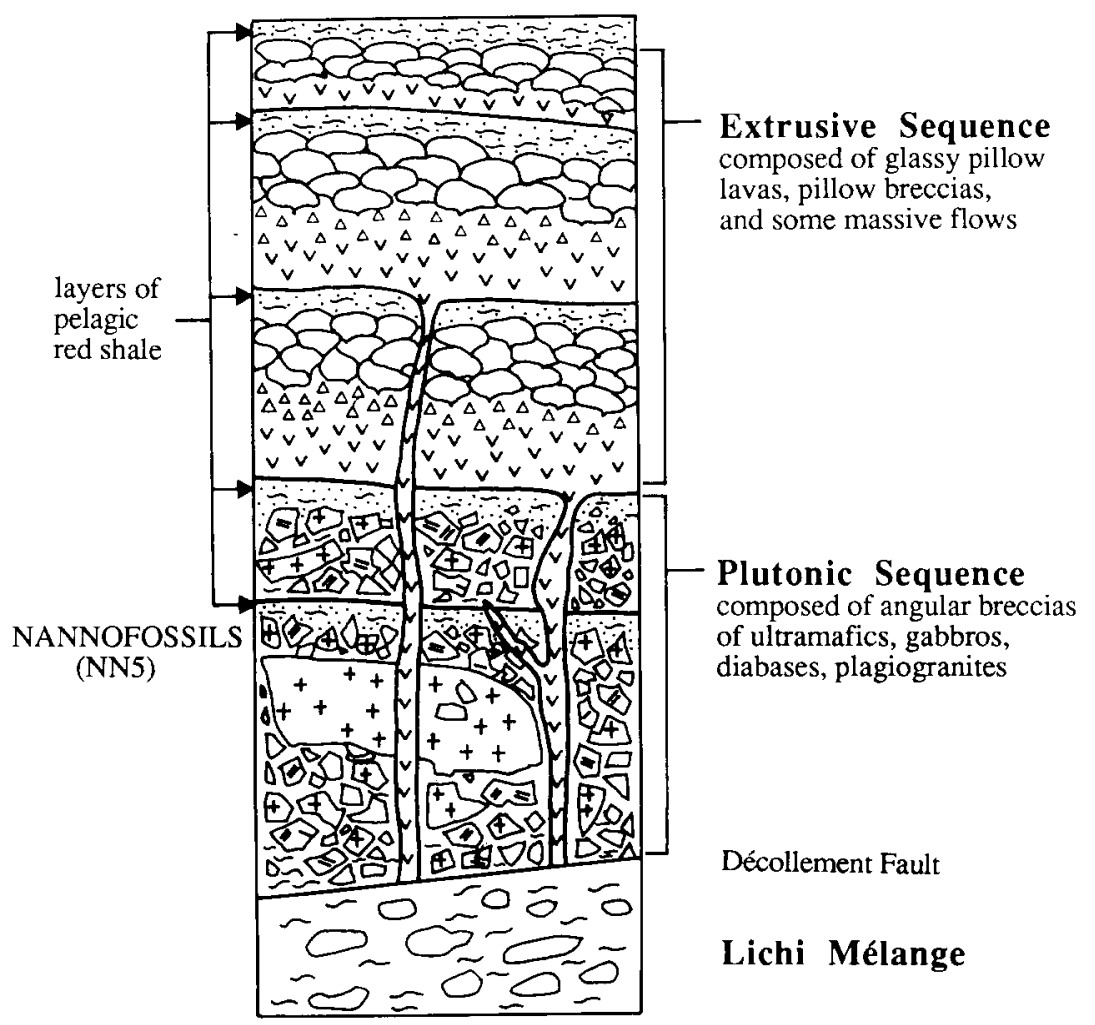

Fig. 3. Schematic stratigraphic section of the ETO (after Liou et al. [7]). Note that the ETO consists of two igneous units and the lowermost red-shale layer contains calcareous nannofossils of zone NN5 ( $\sim 15 \mathrm{Ma}$ ). 
posed of serpentinized peridotites and gabbros and the upper extrusive sequence of basaltic lavas usually marked by pillow structure. The red shales, indicating an unconformable contact, occur between these two units in many places. However, along the Chia-wu-chi (name of a brook), east of Kuanshan (Fig. 2), some basaltic lavas with a chilled margin directly overlie the peridotites. Accordingly, Wang [6] concluded that "the pillow sequence may have been poured out through submarine eruption on a sea floor where at least some basic and ultrabasic plutonics had been exposed". The red shales consist mainly of pelagic sediments with very little calcareous materials, suggesting deposition below the calcite compensation depth [22]. They were thus presumed to be deposited far from land in water depths greater than $4 \mathrm{~km}$. The overlying MORBtype basalts were considered as lavas that spilled over from the ridge crest to the older and deeper ocean floor across a transform fault [1].

There are problems in Suppe et al.'s model. First, the proposed ridge morphology is not appropriate to the South China Sea. It is now well established that variation of mid-ocean ridge topography correlates rather well with the spreading rate [23]. The slow-spreading ridges (e.g. the Mid-Atlantic Ridge, with half rate of $1-3 \mathrm{~cm} / \mathrm{yr}$, $[23,24])$ have a wide median valley bounded by rift mountains. Within the broad valley, there is a narrow inner valley, controlled by faults, in which the youngest volcanic activity occurs [25].

The South China Sea Basin is an "Atlantictype" marginal basin bounded by passive continental margins to the north and south, and opened slowly (2.2 to $3.0 \mathrm{~cm} / \mathrm{yr}$ ) [15]. Consequently an Atlantic-type ridge morphology can be inferred. This suggestion is further supported by the bathymetric studies of the extinct spreading axis [26].

Additional inconsistencies of the earlier genetic model for the ETO include the following: (1) If the scree deposits were formed along an active transform fault, they should have incorporated some fragments of the basaltic lavas. This is not the case since basaltic blocks are very rare in the scree deposits $[1,6,7]$. (2) If the suggested age-depth relationships of the ETO is correct, a transform fault with at least $20 \mathrm{Ma}$ offset (440-600 $\mathrm{km}$ ) is required. This is very unlikely for a small marginal basin with a short spreading history (32-15 Ma). (3) Some massive, not brecciated, peridotites existing along the Chia-wu-chi (i.e. Chia-wu brook) are directly capped by basaltic pillow lavas with chilled margin between the contact. (4) The chemical and isotopic data indicate that the basaltic lavas of ETO may not be typical MORB.

\subsection{Analogues of the ETO: modern and ancient}

Recent studies of the slow-spreading MidAtlantic Ridge show that in many areas the basaltic lavas of layer 2 are very thin or even locally missing [cf. 27]. Extensive deep drilling, dredging and diving programmes in the MidAtlantic regions away from the transform fault or fracture zones have shown surprisingly that, in places, serpentinized peridotites and/or gabbros are overlain by only a thin cover of basaltic lavas or sediments. Elsewhere they even crop out directly on the ocean floor [27-29]. Similar relationships can be seen in older Atlantic crust. This feature seems to be common at the slow-spreading centres, possibly related to limited, discontinuous magma supply and long periods of tectonic extension. The plutonics might be exposed as a result of block faulting and/or detachment faulting [30-32].

Furthermore, similar relationships are seen in many Mesozoic Tethyan, e.g. the Alpine-Apennine, ophiolites [27,33]. Instead of previous "abnormal" ocean basin interpretation for genesis [e.g. 33], a slow-spreading, Atlantic-type origin has recently been argued for this ancient analogue of the ETO [27].

\subsection{A new genetic model for the ETO}

On the basis of new informations at slowspreading ridges, we propose that the ETO was formed in the South China Sea at a normal Atlantic-type mid-ocean environment (Fig. 4).

The South China Sea was characterized by a broad median valley bounded with rift mountains predominantly consisting of exposed peridotites and gabbros, from which sedimentary scree deposits were derived as a response to block faulting and landslides. By the end of spreading, substantial subsidence of the South China Sea Basin 


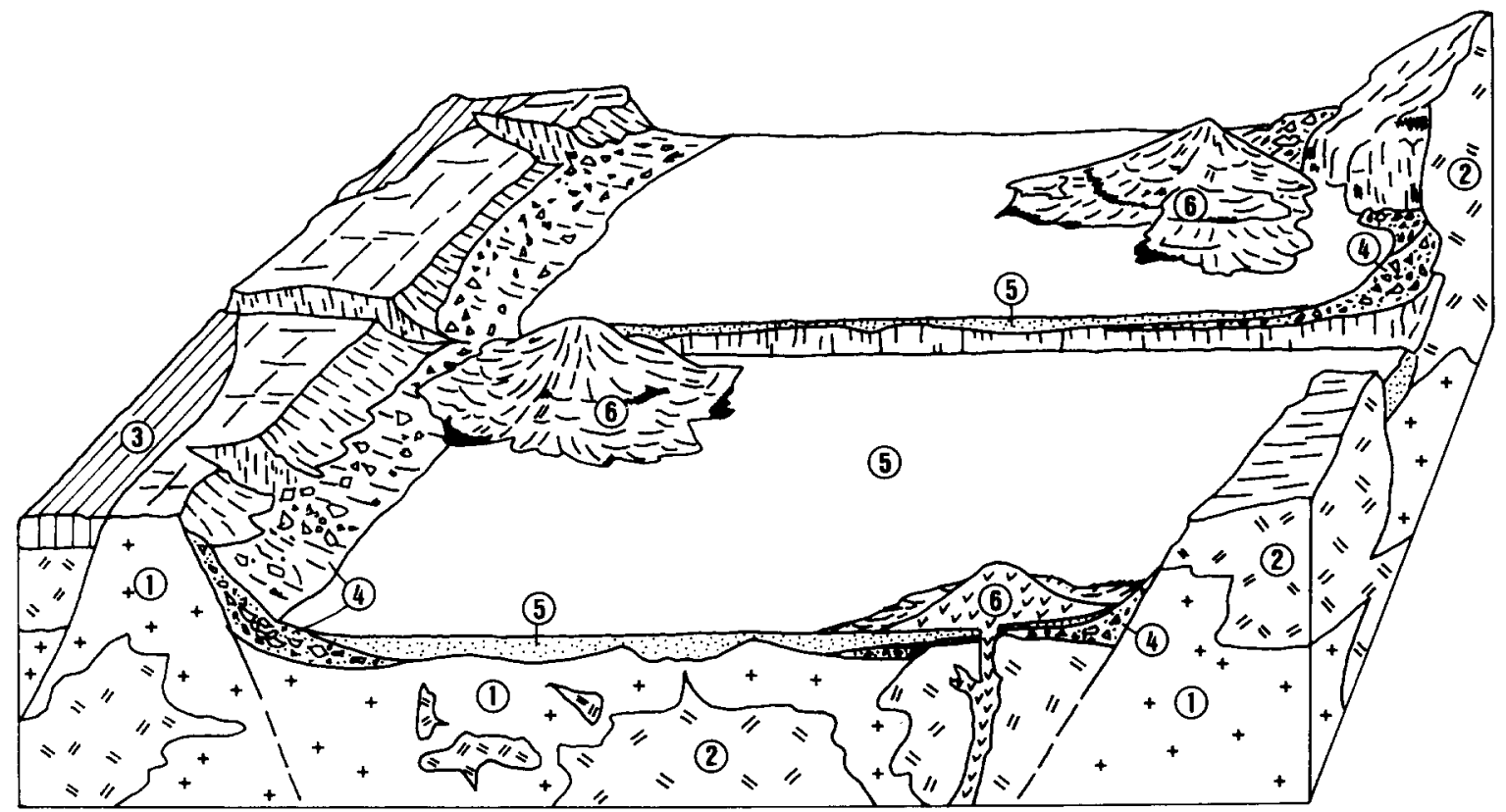

Fig. 4. Schematic reconstruction, after models for the Mid-Atlantic Ridge and the Mesozoic Tethys [27], of the South China Sea spreading axis during Miocene time (about $15 \mathrm{Ma}$ ): $l=$ serpentinized peridotites; $2=$ gabbros; $3=\mathrm{N}-\mathrm{MORB} ; 4=$ ancient scree deposits composed of ultramafic and mafic breccias; $5=$ pelagic red shales; $6=$ isolated near-ridge seamounts erupted by the end of the South China Sea spreading. Note that the red shales, shown by exaggerated thickness, cover most parts of the broad median valley and the seamount basalts directly overlie the serpentinized peridotites, gabbros and/or scree deposits.

was prevailing due to the onset of thermal contraction [15,34]. Pelagic red shales, then, began to be deposited intermittently upon the median valley during periods of tectonic and igneous quiescence. Only six collected from the lowermost shale layer (Fig. 3) as cementing matrix of the plutonic breccias, out of a total of 71 ETO redshale samples studied by Huang et al. [22], contain calcareous nannofossils of solution-resistant genera belonging to the Early to Middle Miocene nannofossil zone NN5 (i.e. about $15 \mathrm{Ma}$ ). Others from the better-developed upper layers show no trace of calcareous materials [22]. This indicates that the red shales were deposited on a subsiding environment, changing from above to below the calcite compensation depth $(\sim 4 \mathrm{~km})$.

Isolated near-ridge seamounts erupted discontinuously in the broad median valley with axial depth of about $4 \mathrm{~km}$ (see next section for further discussion). They may overlie the red shales, scree deposits or even massive plutonic basement with chilled margins. The "classical" sequence of oceanic crust is also drawn in Fig. 4, although only in subordinate position because of its scarcity in the scree deposits. Jahn [2] has published one $\mathrm{K}$-Ar age for fresh ETO basalt glass $(14.6 \pm 0.4$ Ma) which is consistent with the fossil age $(\sim 15$ Ma). Evidently, the near-ridge seamount basalts were erupted during the very final stage of the South China Sea spreading.

\section{The ETO basalts of near-ridge seamount ori- gin}

Most geochemical and petrological studies [2,7,18,35-37] suggested the ETO basalts to be MORB-type magmas. However, an island arc origin was also proposed $[8,9,38]$. To resolve this controversy, Jahn [2] reported additional data and integrated the overall geochemical and isotopic compositions of the representative rock types. He concluded that the ETO is truly "oceanic" in nature, and strongly argued for a midocean or marginal basin origin which was further supported by an immobile trace element study using discrimination diagrams [19]. Moreover, an association of N-type (LRE-depleted) and P-type (LRE-enriched) ETO basalts within a small area 
TABLE 1

The mean major element compositions (wt.\%)

\begin{tabular}{|c|c|c|c|c|}
\hline & \multicolumn{2}{|l|}{ ETO basalts } & \multirow{2}{*}{$\begin{array}{l}\text { MORB } \\
N=590\end{array}$} & \multirow{2}{*}{$\begin{array}{l}\text { NRSB } \\
N=45\end{array}$} \\
\hline & $\begin{array}{l}\text { LRE-depleted } \\
N=29\end{array}$ & $\begin{array}{l}\text { LRE-enriched } \\
N=2\end{array}$ & & \\
\hline$\overline{\mathrm{SiO}_{2}}$ & $49.34(1.16)$ & $49.88(0.91)$ & 50.53 & 49.56 \\
\hline $\mathrm{TiO}_{2}$ & $0.94(0.20)$ & $1.09(0.02)$ & 1.56 & 1.19 \\
\hline $\mathrm{Al}_{2} \mathrm{O}_{3}$ & $15.73(0.65)$ & $16.32(0.25)$ & 15.27 & 16.12 \\
\hline $\mathrm{FeO}_{\mathrm{t}}$ & $10.10(0.72)$ & $9.72(0.41)$ & 10.46 & 9.31 \\
\hline $\mathrm{MnO}$ & $0.15(0.02)$ & $0.15(0.02)$ & 0.16 & 0.15 \\
\hline $\mathrm{MgO}$ & $8.87(0.69)$ & $7.70(0.05)$ & 7.47 & 8.29 \\
\hline $\mathrm{CaO}$ & $11.14(0.81)$ & $10.79(0.08)$ & 11.49 & 12.48 \\
\hline $\mathrm{Na}_{2} \mathrm{O}$ & $2.49(0.30)$ & $2.63(0.20)$ & 2.62 & 2.60 \\
\hline $\mathrm{K}_{2} \mathrm{O}$ & $0.15(0.08)$ & $0.49(0.11)$ & 0.16 & 0.06 \\
\hline $\mathrm{P}_{2} \mathrm{O}_{5}$ & $0.10(0.02)$ & 0.20 & 0.13 & 0.13 \\
\hline $\mathrm{Mg} \#$ & 63.6 & 61.3 & 58.8 & 64.0 \\
\hline $\mathrm{Na}_{8.0}$ & 2.82 & & 2.43 & \\
\hline $\mathrm{CaO} / \mathrm{Al}_{2} \mathrm{O}_{3}$ & 0.71 & & 0.75 & \\
\hline Inferred axial depth & $\sim 4 \mathrm{~km}$ & & $\sim 3 \mathrm{~km}$ & \\
\hline
\end{tabular}

The values between parentheses represent a standard deviation of $1 \sigma$.

Sources: the ETO basalts [2,8,35,36]; MORB [48]; NRSB (near-ridge seamount basalts) [45].

$\mathrm{FeO}_{\mathrm{t}}$ represents total $\mathrm{FeO}$ determination. $\mathrm{Mg} \#$ is calculated by $100 \mathrm{Mg} /(\mathrm{Mg}+\mathrm{Fe})$ assuming $\mathrm{FeO}=0.9 \mathrm{FeO},[45]$. $\mathrm{Na}_{80}$ and inferred axial depth calculations are according to Klein and Langmuir [46].

TABLE 2

Summary of geochemical and petrographic characteristics of the ETO basalts in comparison with MORB and near-ridge seamount basalts (NRSB)

\begin{tabular}{|c|c|c|c|c|}
\hline \multicolumn{3}{|c|}{ Geochemical } & \multicolumn{2}{|l|}{ Petrographic } \\
\hline$\overline{\mathrm{MgO}}$ & $(\mathrm{La} / \mathrm{Sm})_{\mathrm{n}}$ & $\epsilon_{\mathrm{Nd}}$ & Pheno./matrix & $\begin{array}{l}\text { Effect of } \\
\text { hydroth. } \\
\text { alter. }\end{array}$ \\
\hline \multicolumn{5}{|c|}{ ETO basalts } \\
\hline 8.77 & $\begin{array}{l}0.46 \\
\text { to } \\
2.02\end{array}$ & $\begin{array}{l}+13.3 \\
\text { to } \\
+8.7\end{array}$ & $\begin{array}{l}5-18 \% \text { microphenocrysts } \\
\text { (95-82\% glass) composed } \\
\text { of } \mathrm{Ol}(\mathrm{Fo}=86.2-84.6) \text {, Plag, } \\
\mathrm{Cr}-\mathrm{Sp} \text { and absence of } \mathrm{Cpx}\end{array}$ & rare \\
\hline \multicolumn{5}{|c|}{$M O R B$} \\
\hline 7.60 & $\begin{array}{l}0.40 \\
\text { to } \\
3.04\end{array}$ & $\begin{array}{l}+13 \\
\text { to } \\
+7\end{array}$ & $\begin{array}{l}20-30 \% \text { phenocrysts composed } \\
\text { of } \mathrm{Ol}, \mathrm{Cr}-\mathrm{Sp}, \mathrm{Plag},(\mathrm{Cpx}, \\
\text { Fe-Ti oxides) }\end{array}$ & common \\
\hline \multicolumn{5}{|l|}{$N R S B$} \\
\hline 8.20 & $\begin{array}{l}0.31 \\
\text { to } \\
2.81\end{array}$ & $\begin{array}{l}+12 \\
\text { to } \\
+5\end{array}$ & $\begin{array}{l}1-20 \% \text { phenocrysts composed } \\
\text { of Ol, Plag, } \mathrm{Cr}-\mathrm{Sp} \text { and } \\
\text { absence of } \mathrm{Cpx}\end{array}$ & rare \\
\hline
\end{tabular}

Sources: ETO basalts [2,8,9,35-37]; MORB [47-50]; NRSB [24,41-45].

* $(\mathrm{La} / \mathrm{Sm})_{\mathrm{n}}$ due to range of different segments for MORB (both $\mathrm{N}$ - and E-type) but a single seamount for NRSB (seamount 6 , EPR, [41]).

Pheno. $=$ phenocryst $; \mathrm{OI}=$ olivine $; \mathrm{Plag}=$ plagioclase $; \mathrm{Cr}-\mathrm{Sp}=$ chromium spinel $\mathrm{Cpx}=$ clinopyroxene. 
near Kuanshan [2,9] was considered as a mixing result of a highly depleted asthenosphere and an enriched plume-type or hot-spot source [2].

It is important to note the result of the metamorphic history studies of the ETO $[7,39,40]$. The brecciated plutonic rocks have been subjected to two stages of post-magmatic recrystallization, namely the ocean-ridge metamorphism and the later off-axis ocean-floor metamorphism (mainly attained to greenschist facies and zeolite facies mineral assemblages, respectively). However, the overlying basalts have been subjected only to zeolite facies metamorphism. In view of the supposed time gap (perhaps over $10 \mathrm{Ma}$ [40]), the ETO basalts may not be genetically related to the plutonics.

The petrological and geochemical characters of ETO basalts show strong affinities with the near-ridge seamount magmatism which has recently become better-understood as a result of numerous studies [e.g. 24,41-45]. The "seamount effect" [42] is capable of sampling small-scale heterogeneity in a veined or plum-pudding-type mantle source of MORB. Therefore, near-ridge seamount basalts are characterized by chemically heterogeneous and less fractionated compositions compared to MORB originated from the same mantle source.

The ETO basalts have predominantly Ol-Hy normative compositions $[2,7,8]$. They contain higher average $\mathrm{Mg} \#$ of 63.6 for LRE-depleted and 61.3 for LRE-enriched basalts (Table 1) than average MORB $(\mathrm{Mg} \#=58.8)$, but in good agreement with near-ridge seamount basalts $(\mathrm{Mg} \#=$ 64.0). More strikingly, the ETO basalts are characterized by a large proportion of glass, enclosing microlites and/or microphenocrysts of olivine $(F o=84.6-86.2)$, plagioclase $(\mathrm{An}=70-72)$ and minor chrome spinel, whereas clinopyroxene is always lacking (Table 2). Except for pervasive palagonization along cracks and veins, the glass portions are usually very fresh and lack evidence of hydrothermal alteration [7,8,35]. Moreover, as mentioned, samples from a small area display a considerable heterogeneity in abundances of incompatible elements, $\mathrm{La} / \mathrm{Sm}$ ratios and $\mathrm{Nd}$ and $\mathrm{Pb}$ isotope compositions [2,9,37]. All these characteristics, combined with the specific field occurrence and eruption age, lend strong supports to show that ETO basalts are products of near-ridge seamounts.

The major element chemistry of ocean ridge

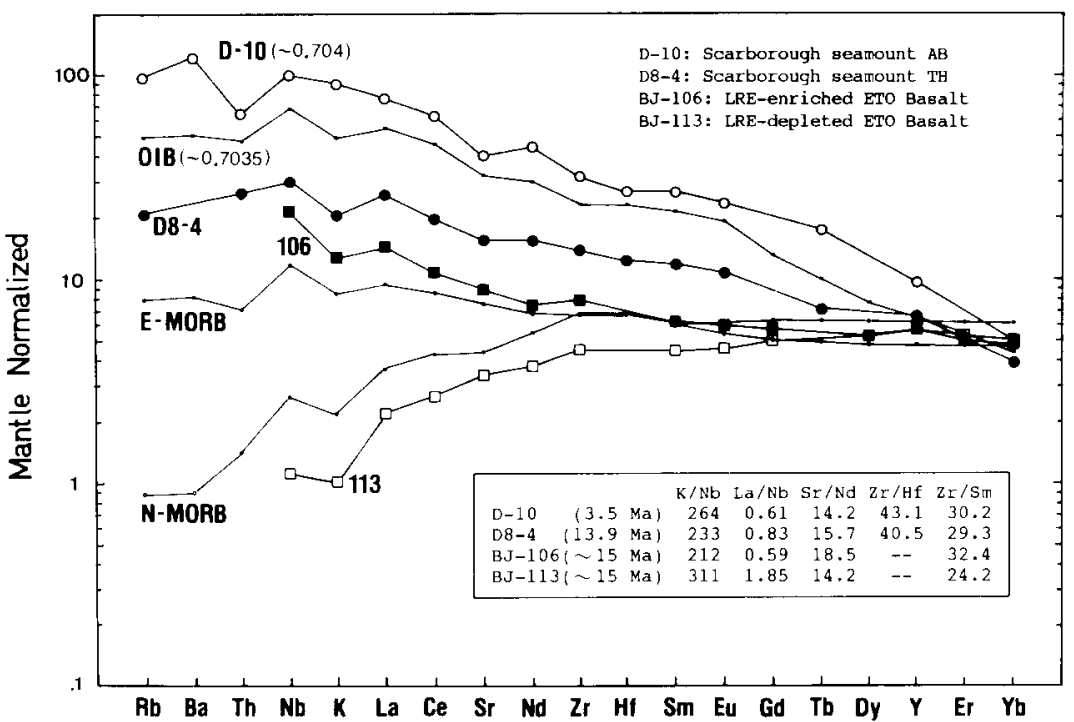

Fig. 5. The primitive-mantle-normalized patterns for some representative ETO and Scarborough seamount basalts generated from the spreading centre of the South China Sea. The formation ages and some elemental ratios are shown for reference. The normalizing values and comparative patterns (e.g. N- and E-MORB and OIB) are from Sun and McDonough [51]. Note that the $\mathrm{OIB}$ is of a non-Dupal type with ${ }^{87} \mathrm{Sr} /{ }^{86} \mathrm{Sr} \sim 0.7035$ while the Scarborough alkali basalt (D-10) has Dupal character with ${ }^{87} \mathrm{Sr} /{ }^{86} \mathrm{Sr} \sim 0.7040$. Data from $[2,55]$. 
basalts show a global correlation with the axial depth [46]. Although seamount magmas may have anomalous chemistry, the average composition of the ETO basalts appears to be of significance (Table 1). The ETO basalt chemistry (e.g. $\mathrm{Na}_{8.0}$ $\left.=2.82, \mathrm{CaO} / \mathrm{Al}_{2} \mathrm{O}_{3}=0.71\right)$ suggests that these basalts did originate from an axis region with a depth of about $4 \mathrm{~km} \mathrm{[46],} \mathrm{consistent} \mathrm{with} \mathrm{the}$ presumed South China Sea axial depth based on the red-shale deposition.

The primitive-mantle-normalized patterns for some representative LRE-depleted and enriched ETO basalts show good internal consistency, except for several mobile elements (e.g. $\mathrm{Rb}$ and Th). They are shown by BJ-113 and BJ-106, respectively, in Fig. 5. Patterns for the $\mathrm{N}$ - and E-type MORB are also shown for comparison. The ETO basalts have $\mathrm{Sr} / \mathrm{Nd}$ ratios similar to MORB and intraplate basalts, close to the chondritic ratio $(\mathrm{Sr} / \mathrm{Nd}=15.5$, [51]). No detectable relative HFSE-depletions, and thus no subduction-related component can be observed.

\section{The post-spreading seamount basalts in the South China Sea}

The ETO is the best material currently available for investigating the structure and chemistry of the ocean floor of the South China Sea. Ophiolites from Mindoro and Palawan are two other possible candidates. They are, however, not as well preserved and studied. In addition, there are a few surveys at seamounts within the South China Sea [e.g. 15,52]. Some dredged samples from these post-spreading seamounts have been studied for chemical and isotopic compositions which show typical intraplate OIB-type characteristics [53-55].

The post-spreading seamounts were mostly erupted adjacent to the continental fragments scattered along the margins of the South China Sea Basin [15,52]. A few exceptions, such as the Scarborough seamounts, are located close to or within the extinct spreading axis (Fig. 1). The Scarborough basalts yield average $\mathrm{K}-\mathrm{Ar}$ and ArAr ages ranging from 13.9 to $3.5 \mathrm{Ma}$ [56]. During this period, it is significant to note that the magmas gradually change from OIB-type olivine tholeiitic to transitional and finally to alkalic basalts.
A simple binary mixing model for a veined or plum-pudding-type mantle source can explain the origin of near-ridge seamount lavas changing from depleted tholeiitic to relatively enriched alkalic basalts [e.g. 42,44]. The continuous chemical variation, from the depleted and enriched ETO basalts to the Scarborough tholeiitic and alkali basalts (Fig. 5), seems to imply their genetic con-

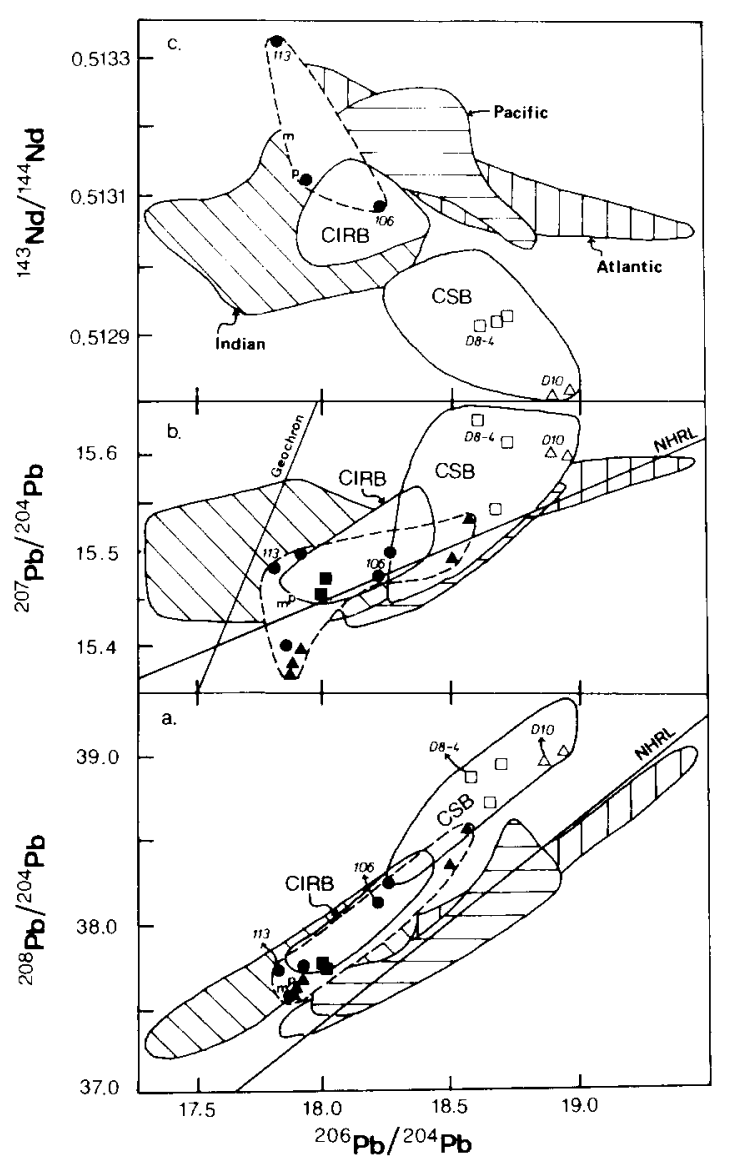

Fig. 6. ${ }^{2018} \mathrm{~Pb} /{ }^{204} \mathrm{~Pb}(\mathrm{a}),{ }^{207} \mathrm{~Pb} /{ }^{204} \mathrm{~Pb}(\mathrm{~b})$, and ${ }^{143} \mathrm{Nd} /{ }^{144} \mathrm{Nd}(\mathrm{c})$ vs. ${ }^{206} \mathrm{~Pb} /{ }^{204} \mathrm{~Pb}$, for the ETO basalts (filled symbols) and Scarborough seamount basalts (open symbols) originated from the South China Sea. Data sources for the ETO include: Chou et al. [9], Jahn [2] and Sun [37] presented as triangles, circles and squares, respectively. The values for the Scarborough tholeiitic (squares) and alkali basalts (triangles) are taken from Tu et al. [55]. The pillow basalts from the Mindoro $(\mathrm{m})$ and Palawan $(p)$ ophiolites, both from [55], are also plotted. For comparison fields of the Central Indian Ridge MORB (CIRB) [63] and the Circum-SCB basalts (CSB) [65] are also drawn. Fields for isotopic data from the North Atlantic, Pacific and Indian Ocean N-MORB are shown by hatched areas. The Northern Hemisphere Reference Line (NHRL) is based on Hart [10]. 
nection and reinforces the validity of binary mixing as the genetic process of the South China Sea basalts.

This binary mixing hypothesis is also supported by the isotope systematics (Fig. 6). The isotope compositions of ETO and Scarborough basalts demonstrate a similar variation corresponding to their chemical characteristics. These chemical and isotopic variations could be caused by different degrees of partial melting from a veined or plum-pudding-type heterogeneous mantle source. The enriched component (i.e. the plum, enriched in LRE and other incompatible clements as well as radiogenic isotopes) is supposed to contain a higher volatile content, and therefore to have a lower solidus temperature than that of the depleted component (i.e. the pudding or N-MORB mantle source). Compared to the ETO basalts, the Scarborough basalts were derived from smaller degrees of melting due to gradual cooling beneath the extinct axis region, which would account for the more enriched chemical and isotopic characteristics in the younger post-spreading South China Sea basalts.

Studies on the southeast China (i.e. FujianTaiwan region) basalts and mantle xenoliths contained therein show that the southeast China lithosphere has been severely stretched, as a poor-developed counterpart of the South China Sea spreading, in association with asthenosphere upwelling [57]. Decompressional melting of a plum-pudding-type convecting mantle, generated by thermal erosion or delamination of the lithospheric mantle, can explain the spatial chemical and isotopic variations of southeast China basalts [57]. The same processes might have taken place prior to or during the formation of South China Sea [58].

\section{Dupal-type domains in the Northern Hemi- sphere}

The $\mathrm{Pb}$ isotope compositions of the ETO and Scarborough basalts, both originated from the South China Sea axis region at about $15^{\circ} \mathrm{N}$, are distinctive by having positive $\Delta^{208 / 204} \mathrm{~Pb}$ values (from 31 to 56 for the former and 45 to 74 for the later, respectively) above the Northern Hemisphere Reference Line (NHRL) consistent with the EM2 Dupal character (Fig. 6a). The South
China Sea appears to be the only province of the Northern Hemisphere where EM2 Dupal-type $\mathrm{Pb}$ compositions have been found in the well-developed mid-oceanic regions. Understanding its origin is critical to further evaluate the following controversies. (1) Is the Dupal anomaly limited to the Southern Hemisphere as originally suggested by Hart [10]? (2) Is it of deep convecting mantle or shallow continental lithospheric mantle origin, or could it be both? (3) What is the mechanism(s) for producing such an isotopic anomaly [e.g. $10,51,59-62]$ ?

Strontium isotope analysis has been attempted by several authors [e.g. 9 and Shih, unpublished] on the ETO basalts and leached powders. However, no success has been achieved to totally eliminate all effects of palagonization due to sea-water-rock interaction. Therefore, $\mathrm{Sr}$ isotope data will not be discussed in this paper.

In comparison with the ${ }^{208} \mathrm{~Pb} /{ }^{204} \mathrm{~Pb}$ ratios, the ${ }^{207} \mathrm{~Pb} /{ }^{204} \mathrm{~Pb}$ ratios of ETO basalts are not as distinctive (Fig. 6b). This feature is very similar to that of the MORB glasses from the Central Indian Ridge [63]. In addition, two ophiolitic basalts from Mindoro and Palawan [55], probably also originating from the South China Sea spreading $[20,64]$, show similar Dupal-type $\mathrm{Pb}$ isotope configurations undistinguishable from the depleted ETO basalts (Fig. 6). This finding confirms the existence of a presumed ancient Dupal component [65] in the convecting mantle of the South China Sea.

Mukasa et al. [66] first recognized the presence of a Dupal-type isotopic anomaly in the Philippine arc volcanics and pointed out that the Dupal anomaly may not be restricted to the Southern Hemisphere mantle. Later, Flower et al. [58] proposed that the Philippine volcanics share the same isotopic characteristics of Cenozoic intraplate basalts from the South China Sea (SCS) post-spreading seamounts, Hainan Island, and southeast China provinces including Fujian, Penghu Islands and northern Taiwan. They further defined a circum-SCS EM2 Dupal-type mantle domain $[55,65]$. In the absence of geophysical evidence for a mantle plume, an origin of shallow lithospheric mantle, overprinted by recent sediment subduction, was postulated [65].

The palaeomagnetic and palaeontologic data [e.g. 67,68] suggested that South China was a part 
of Gondwanaland and drifted since the late Palaeozoic to the Northern Hemisphere. This Gondwana connection may explain the northward extension of the Dupal region in the South China Sea, i.e. it was transported from the Southern Hemisphere either through northward migration of a Dupal-type convecting mantle [10] and/or delamination of a Gondwana-type lithospheric mantle [63]. However, this is not a unique solution. If the EM2 anomaly has indeed originated from modification of lithospheric mantle by subduction of sediments, it could have taken place anywhere on the Earth. A Gondwana connection is not required.

In addition to the South China Sea of the western Pacific in the Northern Hemisphere, the existence of an EM1-type Dupal anomaly in the Japan Sea and NE China has also been suggested [51,69]. Nakamura et al. [70] first reported a Dupal-type $\mathrm{Pb}$ isotope composition with very high $\Delta^{208 / 204} \mathrm{~Pb}$ (about +150 ) in a leucitite from Ulungdo Island in the Japan Sea. These leucitites have ${ }^{87} \mathrm{Sr} /{ }^{86} \mathrm{Sr} \approx 0.705$ and $\epsilon_{\mathrm{Nd}} \approx-2$ [71]. This finding was recently confirmed by Tatsumoto [69]. A mantle plume origin for the volcanism in Japan Sea was proposed by Nakamura et al. [70,71]. However, Sun and McDonough [51] and Tatsumoto [69] favour a lithospheric mantle connection for the observed EM1 Dupal anomaly.

As a concluding remark, we would like to emphasize that although a deep mantle plume connection for EM1-type ocean islands in the Southern Hemisphere Dupal anomaly regions has been well established, the origin of Dupal anomaly domains in the Northern Hemisphere as observed in the South China Sea and the Japan Sea deserves further detailed study. Their existence in the Northern Hemisphere raise some questions. Why should the Dupal anomaly regions be mainly concentrated in the Southern Hemisphere [10]? Is it related to the fundamental lower mantle convection patterns [61] or a frequent near-equatorial aggregation of supercontinent throughout the geological time?

\section{Acknowledgements}

Constructive comments and discussions with B.M. Jahn, U. Knittel, L.S. Teng, and Y. Wang are greatly appreciated. We also acknowledge
Kan Tu for permission to quote his works in advance to publication. S.L. Chung is most grateful to Prof. C-H. Chen for his moral support and continual encouragement. S.-s. Sun acknowledges financial support from the National Science Council (R.O.C.) for his three-month visit to the Institute of Geology, National Taiwan University in 1990. Most ideas presented in this paper were fermented during this visit. Editorial reviews by $R$. Batiza and an anonymous reviewer provided substantial improvements. J.C. $\mathrm{Lu}$ is thanked for his help in computer editing. S.-s. Sun publishes with permission of the Executive Director of $\mathrm{Bu}$ reau of Mineral Resources, Geology and Geophysics, Australia.

\section{References}

1 J. Suppe, J.G. Liou and W.G. Ernst, Paleogeographic origins of the Miocene East Taiwan Ophiolite, Am. J. Sci. 281, 228-246, 1981.

2 B.M. Jahn, Mid-ocean ridge or marginal basin origin of the East Taiwan Ophiolite: chemical and isotopic evidence, Contrib. Mineral. Petrol. 92, 194-206, 1986.

3 B.M. Page and J. Suppe, The Pliocene Lichi melange of Taiwan: its plate tectonic and olistostromal origin, Am. J. Sci. 281, 193-227, 1981.

4 E. Barrier and J. Angelier, Active collision in eastern Taiwan: the coastal range, Tectonophysics $125,39-72$, 1986.

5 L.S. Teng, Geotectonic evolution of late Cenozoic arccontinent collision in Taiwan, Tectonophysics 183, 57-76, 1990.

6 Y. Wang, Some geologic observations in the Coastal Range, eastern Taiwan, Proc. Geol. Soc. China 9, 86-93, 1966.

7 J.G. Liou, C.Y. Lan, J. Suppe and W.G. Ernst, The East Taiwan Ophiolite: its occurrence, petrology, metamorphism and tectonic setting, Mining Research and Service Organization Special Report, No 1, 212 pp, 1977.

8 V.C. Juan, H.J. Lo and C-H. Chen, Crystallization-differentiation of Taiwanite, Proc. Geol. Soc. China 19, 87-97, 1976.

9 C.L. Chou, H.J. Lo, J.H. Chen and V.C. Juan, Rare earth element and isotopic geochemistry of Kuanshan igneous complex, Taiwan, Proc. Geol. Soc. China 21, 13-24, 1978.

10 S.R. Hart, A large-scale isotope anomaly in the southern hemisphere, Nature 309, 753-757, 1984.

11 R. Seno, The instantaneous rotation vector of the Philippine Sea plate relative to the Eurasian plate, Tectonophysics 42, 209-226, 1977.

12 R. Seno and S. Maruyama, Paleogeographic reconstruction and origin of the Philippine Sea, Tectonophysics 102, $53-84,1984$.

13 P. Tapponnier, G. Peltzer and R. Armijo, On the mechanics of the collision between India and Asia, in: Collision 
Tectonics, M.P. Coward and A.C. Ries, eds., Geol. Soc. London Spec. Publ. 19, pp. 115-157, 1986.

14 P. Tapponnier, R. Lacassin, R.H. Leloup, U. Scharer, D.L. Zhong, H.W. Wu, X.H. Liu, S.C. Ji, L.S. Zhang and J.Y. Zhong, The Ailao Shan/Red River metamorphic belt: Tertiary left-lateral shear between Indochina and South China, Nature 343, 431-437, 1990.

15 B. Taylor and D.E. Hayes, Origin and history of the South China Basin, in: The Tectonic and Geologic Evolution of Southeast Asian Seas and Islands, Part 2, D.E. Hayes, ed., AGU Geophys. Monogr. 27, pp. 23-56, 1983.

16 G. Pautot and C. Rangin, Subduction of the South China Sea axial ridge below Luzon (Philippines), Earth Planet. Sci. Lett. 92, 57-69, 1989.

17 B.H.T. Chai, Structure and tectonic evolution of Taiwan, Am. J. Sci. 272, 389-442, 1972.

18 C.Y. Shih, S.-s.Sun, J.G. Liou, T.P. Yen, J.M. Rhodes and I.C. Hsu, Petrology and geochemistry of the Coastal Range ophiolite of Taiwan, EOS 53, 535, 1972.

19 T.F. Yui and M.H. Yang, Trace element implication of the paleotectonic environment of pillow basalts from the East Taiwan Ophiolite, Proc. Geol. Soc. China 31, 11-23, 1988.

$20 \mathrm{~J}$. Suppe, Tectonics of arc-continent collision on both sides of the South China Sea, Acta Geol. Taiwanica 26, $1-18,1988$.

21 J.G. Sclater, R.N. Anderson and M.L. Bell, The elevation of ridges and evolution of the central Eastern Pacific, J. Geophys. Res. 71, 7888-7915, 1971.

22 T.C. Huang, M.P. Chen and W.R. Chi, Calcareous nannofossils from the red shale of the ophiolite-melange complex, eastern Taiwan, Mem. Geol. Soc. China 3, 131-138, 1979.

23 R. Hekinian, Petrology of the Ocean Floor, 393 pp., Elsevier, Amsterdam, 1982.

24 P. Castillo and R. Batiza, Strontium, neodymium and lead jsotope constraints on near-ridge seamount production beneath the South Atlantic, Nature 342, 262-265, 1989.

25 R.D. Ballard and Tj.H. Van Andel, Morphology and tectonics of the inner rift valley at Lat. $36^{\circ} 50^{\prime} \mathrm{N}$ on the Mid-Atlantic Ridge, Bull. Geol. Soc. Am. 88, 507-530, 1977.

26 J. Mammerickx, R.L. Fisher, F.J. Emmel and S.M. Smith, Bathymetry of the east and southeast Asian seas, Map Chart Ser. MC-17, Geol. Soc. Am. Boulder, Colo., 1976.

27 V. Lagabrielle and M. Cannat, Alpine Jurassic ophiolites resemble the modern central Atlantic basement, Geology $18,319-322,1990$.

$28 \mathrm{~J} . A$. Karson et al., Along axis variations in sea-floor spreading in the MARK area, Nature 328, 681-685, 1987.

29 L.P. Zonenshain, M.I. Kusmin, A.P. Lisitsin, Y.A. Bogdanov and B.V. Baranov, Tectonics of the Mid-Atlantic rift valley between the TAG and MARK areas $\left(26-24^{\circ} \mathrm{N}\right)$ : evidence for vertical tectonism, Tectonophysics 159, 1-23, 1989.

30 G.D. Harper, Tectonics of slow spreading mid-oceanic ridges and consequences of a variable depth to the brittle/ductile transition, Tectonics 4, 395-409, 1985.

31 J.A. Karson, Seafloor spreading on the Mid-Atlantic Ridge: implications for the structure of ophiolites and oceanic lithosphere produced in slow-spreading environ- ments, Proc. Symp. Ophiolites and Oceanic Lithosphere, Troodos, 547-555, 1987.

32 C. Mevel, M. Cannat, P. Gente, E. Marion, J.M. Auzende and J.A. Karson, Emplacement of deep crustal and mantle rocks on the west median valley wall of the MARK area (MAR, 23ํ), Tectonophysics 190, 31-53, 1991.

33 M. Lemoine, G. Boillot and P. Tricart, Ultramafic and gabbroic ocean floor of the Ligurian Tethys (Alps, Corsica, Apennines): in search of a genetic model, Geology 15, 622-625, 1987.

34 K. Ru and J.D. Piggot, Episodic rifting and subsidence in the South China Sea, Am. Assoc. Pet. Geol. Bull. 70, $1136-1155,1986$.

35 J.G. Liou, B.M. Jahn and T.P. Yen, Petrology of East Taiwan Ophiolites, Pet. Geol. Taiwan 13, 59-82, 1976.

36 S.-s. Sun, R.W. Nesbitt and A.Y. Sharaskin, Geochemical characteristics of mid-ocean ridge basalts, Earth Planet. Sci. Lett. 44, 119-138, 1979.

37 S.-s. Sun, Lead isotopic study of young volcanic rocks from mid-ocean ridges, ocean islands and island arcs, Philos. Trans. R. Soc. London 297, 409-455, 1980.

38 V.C. Juan, H.J. Lo and C-H. Chen, Genetic relationship and the emplacement of the exotic basic rocks enclosed in the Lichi melange, Coastal Range, east Taiwan. Proc. Geol. Soc. China 23, 56-68, 1978.

39 J.G. Liou, Zeolite facies metamorphism of basaltic rocks from the East Taiwan Ophiolite, Am. Mineral. 64, 1-14, 1979.

40 J.G. Liou and W.G. Ernst, Oceanic ridge metamorphism of the East Taiwan Ophiolite, Contrib. Mineral. Petrol. 68 , 335-348, 1979.

41 R. Batiza and D. Vanko, Petrology of young Pacific seamounts, J. Geophys. Res. 89, 11235-11260, 1984.

42 A. Zindler, H. Staudigel and R. Batiza, Isotope and trace element geochemistry of young Pacific seamounts: implications for the scale of upper mantle heterogeneity, Earth Planet. Sci. Lett. 70, 175-195, 1984.

43 D.J. Fornari, M.R. Perfit, J.F. Allan, R. Batiza, R. Haymon, A. Barone, W.B.F. Ryan, T. Smith, T. Simkin and M.A. Luckman, Geochemical and structural studies of the Lamont seamounts: seamounts as indicators of mantle processes, Earth Planet. Sci. Lett. 89, 63-83, 1988.

44 D.W. Graham, A. Zindler, M.D. Kurz, W.J. Jenkins, R. Batiza and $\mathrm{H}$. Staudigel, $\mathrm{He}, \mathrm{Pb}, \mathrm{Sr}$ and $\mathrm{Nd}$ isotope constraints on magma genesis and mantle heterogeneity beneath young Pacific seamounts, Contrib. Mineral. Petrol. $99,446-463,1988$.

45 J.F. Allan, R. Batiza, M.R. Perfit, D. Fornari and R.O. Sack, Petrology of lavas from the Lamont seamount chain and adjacent East Pacific Rise, $10^{\circ}$ N, J. Petrol. 30, $1245-$ $1298,1989$.

46 E.M. Klein and C.H. Langmuir, Global correlations of ocean ridge basalt chemistry with axial depth and crustal thickness, J. Geophys. Res. 92, 8089-8115, 1987.

47 W.G. Melson, T.L. Vallier, T.L. Wright, G. Byerly and J. Nelen, Chemistry diversity of abyssal volcanic glass erupted along Pacific, Atlantic and Indian Ocean sea-floor spreading centers, in: The Geophysics of the Pacific Ocean Basin and Its Margin. AGU Geophys. Monogr. 19, 351-367, 1976. 
48 BVSP, Basaltic Volcanism on the Terrestrial Planets, 1286 pp., Pergamon Press, New York, N.Y., 1981.

49 W.B. Bryan, Systematics of modal phenocryst assemblages in submarine basalts: petrologic implications, Contrib. Mineral. Petrol. 83, 62-74, 1983.

50 E. Ito, W.M. White and C. Gopel, The $\mathrm{O}, \mathrm{Sr}, \mathrm{Nd}$ and $\mathrm{Pb}$ isotope geochemistry of MORB, Chem. Geol. 62, 157-176, 1987.

51 S.-s. Sun and W.F. McDonough, Chemical and isotopic systematics of oceanic basalts: implications for mantle composition and processes, in: Magmatism in the Ocean Basins, A.D. Saunders and M.J. Norry, eds., Geol. Soc. London Spec. Publ. 42, 313-345, 1989.

52 H.R. Kuddras, M. Wiedicke, P. Cepek, H. Kreuzer and P. Muller, Mesozoic and Cainozoic rocks dredged from the South China Sea (Reed Bank area) and Sulu Sea and their significance for plate-tectonic reconstruction, Mar. Petrol. Geol. 3, 19-30, 1986.

53 K. Tu, M.F.J. Flower and R.W. Carlson, Isotopic evidence for the Dupal anomaly in post-spreading magmas from the South China Basin, Chem. Geol. 70, 57, 1988.

54 K. Tu, M.F.J. Flower, G.H. Xie and R.W. Carlson, Decoupled isotope and magmaphile element enrichment in the South China Basin magmas, Abstr., Symp. Geology and Geophysics of the South China Sea, Guangzhou, China, 1989.

55 K. Tu, M.F.J. Flower, R.W. Carlson, G.H. Xie and C.Y. Chen, Magmatism in the South China basin, 1. Isotopic and trace element evidence for an endogenous Dupal mantle component, Chem. Geol. in press, 1991.

56 M. Wang, D. Wu, I. Liang and A. Yin, Some geochemical characteristics of basalts from the South China Sea, Geochimica 4, 332-340, 1984.

57 S.L. Chung, S.-s. Sun, K. Tu and C-H. Chen, Generation of the late Cenozoic basalts in SE China: consequence of continental stretching and asthenosphere upwelling in response to India-Eurasia collision, in prep.

58 M.F.J. Flower, K. Tu, M. Zhang and G.H. Xie, The South China Basin domain: a common source for recent midplate and convergent margin magmas, Abstr. Symp. Geology and Geophysics of the South China Sea, Guangzhou, China, 1989.

59 C.J. Hawkesworth, M.S.M. Mantovani, P.N. Taylor and Z.
Palacz, Evidence from the Parana of South Brazil for a continental contribution to Dupal basalts, Nature 322 , 356-358, 1986.

60 A. Zindler and S.R. Hart, Chemical geodynamics, An. Rev. Earth and Planet. Sci. 14, 493-571, 1986.

61 P.R. Castillo, The Dupal anomaly as a trace of upwelling lower mantle, Nature 336, 667-670, 1988.

62 S.R. Hart, Heterogeneous mantle domains: signatures, genesis and mixing chronologies, Earth Planet. Sci. Lett. 90, 273-296, 1988.

63 J.J. Mahoney, J.H. Natland, W.M. White, R. Poreda, S.H. Bloomer, R.L. Fisher and A.N. Baxter, Isotopic and geochemical provinces of the western Indian Ocean spreading centers, J. Geophys. Res. 94, 4033-4052, 1989.

64 C. Rangin, J.F. Stephan and C. Muller, Middle Oligocene oceanic crust of South China Sea jammed into Mindoro collision zone (Philippines), Geology 13, 425-428, 1985.

65 K. Tu, M.F.J. Flower, R.W. Carlson, M. Zhang and G.H. $\mathrm{Xie}, \mathrm{Sr}, \mathrm{Nd}$ and $\mathrm{Pb}$ isotopic compositions of Hainan basalts (South China): implications for a subcontinental lithosphere Dupal source, Geology 19, 567-569, 1991.

66 S.B. Mukasa, R. McCabe and J.B. Gill, Pb isotopic compositions of volcanic rocks in the west and east Philippine arcs: presence of the Dupal isotopic anomaly, Earth Planet. Sci. Lett. 84, 153-164, 1987.

67 J.L. Lin, M. Fuller and W.Y. Zhang, Preliminary Phanerozoic polar wander paths for the North and South China blocks, Nature 313, 444-449, 1985.

68 K.J. Hsu, J.L. Li, H.H. Chen, Q.C. Wang, S. Sun and A.M.C. Sengor, Tectonics of South China: key to understanding West Pacific geology, Tectonophysics 183, 9-39, 1990.

69 M. Tatsumoto, Dupal anomaly in the Sea of Japan: a plate recycling model of OIB sources, Caltech Plume Symp. Abs., May 2-4, 1991.

70 E. Nakamura, I.H. Campbell and S.-s. Sun, The influence of subduction processes on the geochemistry of Japanese alkaline basalts, Nature 316, 55-58, 1985.

71 E. Nakamura, I.H. Campbell, M.T. McCulloch and S.-s. Sun, Chemical geodynamics in a back-arc region around the Sea of Japan: implications for the genesis of alkaline basalts in Japan, Korea and China, J. Geophys. Res. 94, 4634-4654, 1989. 